\title{
APS Feasibility in an Engineer to Order Environment
}

\author{
Erlend Alfnes ${ }^{1}$, Hans-Henrik Hvolby ${ }^{1,2(\bowtie)}[0000-0002-5574-5216]$ \\ ${ }^{1}$ Department of Mechanical and Industrial Engineering, Norwegian University of Science and \\ Technology, Trondheim, Norway \\ ${ }^{2}$ Centre for Logistics, Department of Materials and Manufacturing Engineering, \\ Aalborg University, Denmark \\ 凶hhh@celog.dk
}

\begin{abstract}
This paper discus the feasibility of using advanced planning and scheduling (APS) in an engineer to order manufacturing company. The starting point is a company producing customised variants of standard products involving engineering, machining, sub-assembly, and final assembly operations. There is limited degree of parts commonality as the product variety is high with respect to material and size. APS is normally used in repetitive manufacturing companies but we argue that some ETO companies with a somewhat fixed planning setup could benefit of implementing an APS engine on top of their ERP system. One of the critical elements is, however, whether the company is able to formalise their tacit knowledge in the complicated planning processes to rules and options in an APS environment.
\end{abstract}

Keywords: Engineer to Order (ETO), One-of-a-kind production (OKP), Advanced Planning and Scheduling (APS), Enterprise Resource Planning (ERP)

\section{Introduction.}

In this paper, we investigate the feasibility of using Advanced Planning and Scheduling (APS) in an engineer to order (ETO) company. APS is mainly used in repetitive manufacturing companies and has become the state-of-the-art within planning and control adding features such as comparing different planning scenarios before plan release.

Manufacturing planning and control systems have gradually developed from simple materials requirements planning towards handling a large variety of core elements in a manufacturing company such as capacity planning, finance, human resources and payrolls $[1,2]$. Enterprise Resource Planning (ERP) and Advanced Planning and Scheduling (APS) systems have improved the integration of materials and capacity planning. While MRP systems merely calculated the materials and capacity requirements, APS systems have the ability to create a feasible plan way faster and better than previous systems which involved a number of iterations with manual adjustments [1,2,3]. APS require good input in terms of data quality and this is more difficult in an ETO company compared to a repetitive manufacturing environment [4]. Further, APS systems are very

adfa, p. 1,2011.

(C) Springer-Verlag Berlin Heidelberg 2011 
expensive and for many small and midsize companies, it is a question as to whether a high investment in an APS system pays off [3].

Engineer-to-order products are engineered to the specific requirements of the customer order [5]. Each customer order results in a unique set of part numbers, bills of material, and routings for manufacturing. The engineer-to-order strategy is suitable for highly customised, capital intensive, one-of-a-kind products [6]. An engineer-to-order strategy implies that engineering is involved in order fulfilment. The level of engineering adaption to customer requirements can range from new product development to minor modifications to an existing product [7]. Engineering and manufacturing activities are often performed concurrently, and engineering changes can happen in all phases of the order fulfilment process, including manufacturing [8]. The engineer-to-order strategy means a high level of uncertainty in terms of product specifications, demand composition, supply and delivery times, and processing times [9].

The engineering process is an iterative process that aims to find the best solution together with customers and suppliers. Since the design of an ETO product is not realised until after the engineering process have been completed, the information available for planning is limited [10]. The final product structure, routings, and processing requirements are not known before detailed engineering is complete. Manufacturing will basically make a new product for each order, and the uncertainty and variations in processing times can be high.

\section{Industry Case.}

This study takes a starting point in a capital intensive Engineer to Order (ETO) case company producing large products with a low to medium engineering complexity. The product structure is deep and includes several sub-assemblies and parts. Manufacturing involves machining, sub-assembly, and final assembly operations. A typical product consists of more than 500 parts, where less than 20 pct. of the parts are engineered to order. There is limited degree of parts commonality as the product variety is high with respect to material and size leading to high inventory levels. The non-customised products stems mainly from one generic unit. Customer orders typically starts with a tender several months ahead. However, it is common that orders are changed in terms of delivery dates and engineering specification adjustments both before and during manufacturing. The design uncertainty is therefore fairly high through the whole order fulfilment process.

Most ETO products are constructed from a mix of parts with different level of customization. There might be cases where the entire product is engineered-to-order. Usually, a large share of the elements has standard design and are made-to-stock or made-to-order. Standard parts and assemblies that are required in low volumes are often made-to-order (or assembled-to-order) while standard parts required in higher volumes are made-to-stock.

To level production and to comply with short lead times, some production orders are initiated before the customer order has been fully specified. Forecasts of expected new orders are used to initialize purchasing to deal with long lead times, as well as 
production of standard items. High volume spare parts are produced to stock whilst low volume and customised parts are produced as rush orders due to the criticality of deliveries.

The company has developed a configurator to generate customer order specification including manufacturing and purchase order input. This involves selection of process flow and estimation of processing times. This enables the company to use an ERP backbone for planning instead of a project management application which some OKP companies favour. Compared to a repetitive manufacturing company this limits to some degree the quality of the detailed planning process due to the uncertainty of the processing times. The main planning processes are described in table 1 .

\begin{tabular}{|c|c|c|c|}
\hline Process & $\begin{array}{c}\text { Sales and operations } \\
\text { planning }\end{array}$ & $\begin{array}{c}\text { Master production } \\
\text { planning }\end{array}$ & Shop floor control \\
\hline $\begin{array}{l}\text { Time hori- } \\
\text { zon }\end{array}$ & $\begin{array}{l}\begin{array}{l}6-18 \text { months before } \\
\text { delivery }\end{array} \\
\end{array}$ & $\begin{array}{l}3-18 \text { months before de- } \\
\text { livery }\end{array}$ & $\begin{array}{l}0-3 \text { months before deliv- } \\
\text { ery }\end{array}$ \\
\hline $\begin{array}{l}\text { Main ob- } \\
\text { jective }\end{array}$ & $\begin{array}{l}\text { Set delivery week for } \\
\text { tenders, and balance } \\
\text { mix to ensure suffi- } \\
\text { cient capacity }\end{array}$ & $\begin{array}{l}\text { Set sequence in order to } \\
\text { compress product } \\
\text { throughput times. }\end{array}$ & $\begin{array}{l}\text { Balance the flow during } \\
\text { manufacturing and han- } \\
\text { dle interruptions }\end{array}$ \\
\hline $\begin{array}{l}\text { Descrip- } \\
\text { tion }\end{array}$ & $\begin{array}{l}\text { Supply planning of in- } \\
\text { ternal capacity (feasi- } \\
\text { ble mix pr. week) and } \\
\text { deliveries from sup- } \\
\text { pliers. }\end{array}$ & $\begin{array}{l}\text { Rough-cut capacity } \\
\text { planning on critical re- } \\
\text { sources to find feasible } \\
\text { product sequence pr. } \\
\text { week. }\end{array}$ & $\begin{array}{l}\text { Monitoring and control of } \\
\text { the flow from fabrication } \\
\text { throughout assembly. }\end{array}$ \\
\hline $\begin{array}{l}\text { ERP- } \\
\text { support }\end{array}$ & $\begin{array}{l}\text { Estimate material and } \\
\text { capacity require- } \\
\text { ments, and to issue } \\
\text { long lead-time pur- } \\
\text { chase orders. }\end{array}$ & $\begin{array}{l}\text { Calculate material and } \\
\text { capacity requirements, } \\
\text { and to issue short lead- } \\
\text { time purchase orders }\end{array}$ & $\begin{array}{l}\text { Keep track of job status } \\
\text { and inventory status. }\end{array}$ \\
\hline $\begin{array}{l}\text { Available } \\
\text { data }\end{array}$ & $\begin{array}{l}\text { Customer design and } \\
\text { delivery preferences, } \\
\text { ERP templates for } \\
\text { similar parts in terms } \\
\text { of BOMs, routings } \\
\text { and processing times. }\end{array}$ & $\begin{array}{l}\text { Final specifications in } \\
\text { terms of BOMs, } \\
\text { routings, and more ac- } \\
\text { curate processing times. }\end{array}$ & $\begin{array}{l}\text { Inventory status } \\
\text { Job status for some work- } \\
\text { stations (started, com- } \\
\text { pleted). }\end{array}$ \\
\hline $\begin{array}{l}\text { Manual } \\
\text { decision } \\
\text { making }\end{array}$ & $\begin{array}{l}\text { Delivery due date set- } \\
\text { ting. Capacity balanc- } \\
\text { ing. Expedite and } \\
\text { postpone manufactur- } \\
\text { ing due dates. } \\
\text { Find alternative re- } \\
\text { sources when over- } \\
\text { load. Make-or-buy } \\
\text { analysis. Supplier se- } \\
\text { lection. }\end{array}$ & $\begin{array}{l}\text { Detailed capacity bal- } \\
\text { ancing on critical re- } \\
\text { sources. Sequencing of } \\
\text { order specific parts. } \\
\text { Decide which MTS } \\
\text { parts and service parts } \\
\text { to produce to fill up } \\
\text { slack capacity Handle } \\
\text { delays in detailed de- } \\
\text { sign and purchased } \\
\text { parts. }\end{array}$ & $\begin{array}{l}\text { Resequencing of machin- } \\
\text { ing and assembly orders } \\
\text { to reduce number of open } \\
\text { orders and delays. Take } \\
\text { countermeasures (e.g. } \\
\text { overtime, reallocation of } \\
\text { operators, re-allocation of } \\
\text { parts between projects) to } \\
\text { increase capacity or ma- } \\
\text { terial availability. }\end{array}$ \\
\hline
\end{tabular}

Table 1: Main planning processes in the case company 
Sales and operations planning (S\&OP) is performed to estimate delivery dates for bids and aftermarket requests. This is a collaborative process that involves other disciplines such as sales and engineering. Only an overall product specification and design exists at the bidding stage, so the material and capacity requirements will not be accurate. The planning involves a high level of human judgement and is mainly performed on standalone tools for rough-cut planning. A small but profitable share of the sales comes from the aftermarket, and these products often need to be delivered on a shorter notice than ordinary products. A main task for the planner is, therefore, to revise the plan in order to include aftermarket orders and still keep customer deadlines for all products.

With regards to master production planning and shop floor control, the main task for the planner is to find a mix of products per week that ensures sufficient capacity on bottleneck resources and, if needed, to add extra capacity in terms of overtime or outsourcing. There are large variations in work content from product to product, so the likelihood of capacity shortage on some critical work stations or machines is high.

A more accurate material requirement planning is performed after the complete and detailed BOM is handed over from engineering. Work orders are generated by the ERP system and released before start of production. The detailed BOM enables the planner to check the real capacity utilization for each critical resource and to make counter measures if required.

When production has started the progress is monitored by the planner to check that all fabricated and purchased parts are available in time for assembly operations. As the assembly stations receives a broad range of manufactured and purchased parts, the risk of delay is substantial. Identified challenges includes rush orders, engineering change orders, supplier delays, defects on incoming parts, lack of pre-fabricated materials, lack of personnel, set-up problems, lack of correct jigs or variations and uncertainty in processing times for customised parts. Further, shop floor operators may request changed sequences to increase efficiency on machine cells. The main task for the planner is to cope with all variations and create a flow of parts that reduces delays in assembly.

\subsection{Summary of planning challenges}

The high degree of customisation, the many engineering changes and the long lead times from suppliers forms a complicated planning environment. On top of this comes the challenges of after sales (rush) orders and a desire to level the production and assembly resources. The challenges are divided in a) short range planning and scheduling and b) long range sales and operations planning:

a) Short range: Most importantly the plan must secure an assembly of products according to customer delivery dates ensuring a balanced capacity load. Different mix configurations generate large variations in work content and shifting bottlenecks. Rescheduling is initiated by customer changes, supplier changes, and shop floor challenges

b) Long range: Most importantly the plan must include rough cut capacity considerations and supplier availability based on accepted orders and tenders. The final product structure, routings, and processing requirements are not known before 
detailed engineering is complete. At this stage, product data, processing times and lead times are estimates from a sales configurator which leads to some uncertainty regarding the capacity and supplier constraints. This includes forecasting on materials and capacity needs are somewhat difficult in a OKP environment due to the uncertainty not only on quantities and models but also actual configuration

\section{$3 \quad$ APS feasibility in an engineer to order company.}

Advanced planning systems utilize complex mathematical algorithms to forecast demand, to plan and schedule production within specified constraints, and to derive optimal sourcing and product-mix solutions. APS seeks to find feasible, near optimal plans while potential bottlenecks are considered explicitly. Unlike ERP, Materials and capacity issues are considered simultaneously and thereby avoiding ERP planning process with multiple recalculations to obtain the feasible plan both materials- and capacity wise.

APS-systems aim at reducing costs of goods sold and to increase customer satisfaction by initiating production at the best time, using an optimal combination of manufacturing resources. This enables the generation of a far more realistic and reliable production plans than ERP systems [1]. When multiple objectives exist in a manufacturing environment, and most of these are in conflict with each another, an approach is needed for modelling and evaluating the trade-off among the conflicting objectives. Here two options exist, constraintbased planning and optimization.

Constrained based planning is based on hard and soft (or goal) constraints. Its distinguished feature is that the objectives can be stated as minimising deviations from pre-specified goals. Hard constraints are not overruled, whereas soft constraints are overruled, if necessary. As no plan optimisation objectives or criteria are considered, this option produces a feasible but not necessarily an optimal plan although a hidden plan objective function minimizing the plan costs is used to drive the planning and trade-off among the soft constraints.

Optimised plans are generated based on plan objectives, penalty factors, and constraints besides the hard and soft constraints. The constraint-based rules are exchanged with decision variables and penalty factors. As in the constraint based plan, hard constraints are not overruled, where soft constraints might be overruled if this reduces the total costs. As an example, overtime work will be preferred in order to avoid late delivery if the penalty for late demand is higher than the penalty for exceeding resource capacity. Industry studies show that optimised plans are rarely used in industry as it is difficult to convert all business decisions into a cost perspective (e.g. late delivery versus overtime work of reduced inventory turns) [4].

As APS is an add-on to ERP, most APS implementations and case studies have been conducted in repetitive manufacturing or process industry (automobile, dairy, oil, steel industry, etc). We have only identified one study on APS in an ETO environment dealing with possible improvements in a shipyard by adding an APS module to the current 
ERP system [10]. As little help on this issue is found in litterature we have chosen to evaluate the pros and cons according to the challenges identified in the previous section

\begin{tabular}{|c|c|}
\hline Planning challenges & APS support \\
\hline $\begin{array}{l}\text { Multiple ERP-run's to adjust the manu- } \\
\text { facturing plan according to capacity } \\
\text { (machines, manpower, and jigs), se- } \\
\text { quence, materials supply, assembly ca- } \\
\text { pacity and customer order lead times }\end{array}$ & $\begin{array}{l}\text { One single APS-run that satisfies all hard } \\
\text { constraints and, if possible, soft con- } \\
\text { strains. The critical issue is the ability to } \\
\text { model all the constraints which the plan- } \\
\text { ner takes into consideration, not least the } \\
\text { estimated process times for new variants. }\end{array}$ \\
\hline $\begin{array}{l}\text { Due-day setting of tenders and new or- } \\
\text { ders, based on rough cut capacity con- } \\
\text { siderations and supplier availability. } \\
\text { Product data and processing times are } \\
\text { estimates from a sales configurator. } \\
\text { Forecasting of materials in spite of un- } \\
\text { certainties regarding final specifica- } \\
\text { tions. }\end{array}$ & $\begin{array}{l}\text { Parts of this decision process are well } \\
\text { supported by APS but the uncertainties in } \\
\text { the engineering phase, as well as the com- } \\
\text { plexity of the sales configurator, makes } \\
\text { the value of APS support more doubtful. } \\
\text { The most valuable functionality is proba- } \\
\text { bly fast what-if scenarios. }\end{array}$ \\
\hline
\end{tabular}

Table 2: Short and long range planning challenges and possible APS support

The modelling and implementation aspects are discussed in the following section

\section{Discussion and conclusion.}

The paper has presented an in-depth single case study in an ETO company with the purpose of identifying the feasibility of implementing an APS module on top of their ERP system. APS functionality in terms of short and long term planning has been discussed both theoretically and in practice. However, an important factor for successful implementation of APS is a correct and consistent model [13]. The modelling aspects will, therefore, be briefly discussed in the following.

A supply chain or a manufacturing system can be simple, complicated, or complex [11]. Simple systems have a small number of well-understood components. Complicated systems have many components that interact through predefined coordination. Linear relationships between components that make the behaviour of the overall system predictable, and hence possible to model. Complex systems on the other hand, typically have many components that can autonomously interact through emergent, non-linear rules. This non-linearity makes it impossible to fully predict the overall systems behaviour by knowing its structure and components and hence makes them challenging to model [12]. Inspired by [11-14] the following table (3) have been constructed: 


\begin{tabular}{|l|l|l|l|}
\hline Factors & $\begin{array}{l}\text { Sales and oper- } \\
\text { ations planning }\end{array}$ & $\begin{array}{l}\text { Master produc- } \\
\text { tion planning }\end{array}$ & $\begin{array}{l}\text { Shop floor } \\
\text { control }\end{array}$ \\
\hline Decisions complicatedness & Medium $(\uparrow)$ & High $(\uparrow)$ & High $(\uparrow)$ \\
\hline Decisions complexity & Medium $(-)$ & Medium $(-)$ & $\operatorname{High}(\downarrow)$ \\
\hline Data availability and quality & Low $(\downarrow)$ & Medium $(-)$ & Medium $(-)$ \\
\hline Uncertainty, disruptions, variations & High $(\uparrow)$ & High $(\uparrow)$ & $\operatorname{High}(\uparrow)$ \\
\hline
\end{tabular}

Table 3: Evaluation of APS support in the case company where $(\uparrow)$ indicates high degree of support etc. Inspired by [11-14]

The planner's value of an APS model is briefly evaluated on 5 factors from table 3 above:

1. Decision complicatedness. Complicated planning problems can be hard to solve because they include many objectives and elements, but they are addressable with rules and recipes and can be modelled.

2. Decision complexity. Complex planning problems involve many unknown and interrelated factors that must be modelled in terms of rules and processes in a model. A valuable APS model must capture sufficient aspects of the planning problem to provide correct decisions support.

3. Level of aggregation. Aggregation is a process for simplifying a problem by defining condensed data and decision variables [13]. An aggregated model will be less complicated and require less data but provide less detailed answers.

4. Data availability and quality. APS systems rely on a significant amount of detailed and accurate data. Basic data such as item data, bill-of material data, routing data and work centre data, as well as operational data such as inventory status, delivery date requirements and resource utilisation. These data has to be available and have sufficient quality in order to make a feasible plan.

5. Uncertainty and variations. APS systems are well-suited for complicated tasks where the demand and supply are uncertain and fluctuating [14]. However, determining production targets and detailed schedules can be significantly influenced by interruptions such as defects, varying processing times, material changes, engineering changes, sequence-rules that are not followed, maintenance stops, rush orders, prototype work, etc. Such factors reduce the planning correctness, as well as frequent updates of the APS plan can create planning nervousness.

Based on the analysis, the pros and cons of APS in an ETO environment and the 5 factors described above, it has been decided to develop tree demonstrators in terms of constraint-based models of 1) Sales and Operations Planning (due-date settings) and 2) Master Production Scheduling (assembly order sequencing) and 3) Shop Floor Control (machine cell job allocation). The outcome of this work will be used in the final decision making as to whether an APS system is likely to improve the current planning setup. The difficult parts of this work is to enrich the current machine data with alternative routes and process times as well as the tacit knowledge of planners and foremen on e.g. machine and operator capabilities which is currently not formalised in the ERPsystem but has a great impact of the useability of the plan. Based on the outcome of the demonstrator a final assessment of the feasibility of implementing APS in the case 
company will be conducted. In case of a fruitful outcome of the demonstrator, the critical elements of the model development will be used as requirements in the selection phase of the best-fit APS system.

\section{$5 \quad$ Acknowledgements.}

We would like to express our gratitude to the Research Council of Norway (MAROFF) for financial support as well as the engaged contribution from the case company representatives involved in this research.

\section{References.}

1. Jacobs, F \& Weston, F C (2007), "Enterprise resource planning (ERP) - A brief history", Journal of Operations Management vol. 31, p 357-363.

2. Hsu, T-H; Wang, L-I \& Chu, P-C (2018) "Development of a Cloud-based Advanced Planning and Scheduling System", Flexible Automation and Intelligent Manufacturing (FAIM2018).

3. Slack, N; Brandon-Jones, A \& Johnston, R (2013), "Operations Management", Sixth Edition, Pearson.

4. Kjellsdotter, L \& Jonsson, P (2011) "Problems in the onward and upward phase of APSsystem implementation: Why do they occur?", International Journal of Physical Distribution \& Logistics Management, vol 41, issue 4, p 343-363.

5. Haug, A, Ladeby, K \& Edwards, K "From engineer-to-order to mass customization." Management Research News 32.7 (2009): 633-644.

6. Adrodegari, F., Bacchetti, A., Pinto, R., Pirola, F., \& Zanardini, M. (2015). "Engineer-toorder (ETO) production planning and control: An empirical framework for machinery-building companies". Production Planning \& Control, 26(11), 910-932.

7. Amaro, G., Hendry, L., \& Kingsman, B. (1999). "Competitive advantage, customisation and a new taxonomy for non make-to-stock companies". International Journal of Operations \& Production Management, 19(4), 349-371.

8. Wikner, J., \& Rudberg, M. (2005). "Integrating production and engineering perspectives on the customer order decoupling point". International Journal of Operations \& Production Management, 25(7), 623-641.

9. Grabenstetter, D. H., \& Usher, J. M. (2014). "Developing due dates in an engineer-to-order engineering environment". International Journal of Production Research, 52(21), 6349-6361.

10. SeungHoon, N; HuiQiang, S; Cheolho, R and Jong, G S (2018): SCP-Matrix based shipyard APS design, Int. Journal of Naval Architecture and Ocean Engineering vol 10 p 741-761

11. Pathak, S. D., Day, J. M., Nair, A., Sawaya, W. J., \& Kristal, M. M. (2007). Complexity and adaptivity in supply networks: Building supply network theory using a complex adaptive systems perspective. Decision sciences, 38(4), 547-580.

12. Weichhart, G, Molina, A, Chen, D, Whitman, L E, \& Vernadat, F (2016). Challenges and current developments for sensing, smart and sustainable enterprise systems. Computers in Industry, 79, 34-46.

13. Zoryk-Schalla, A. J., Fransoo, J. C., \& de Kok, T. G. (2004). Modeling the planning process in advanced planning systems. Information \& Management, 42(1), 75-87.

14. Ivert, K.L. \& Jonsson P. (2014), "When should advanced planning and scheduling systems be used in sales and operations planning?", International Journal of Operations and Production Management, Vol. 34, No. 10, pp.1338-1362. 